\title{
NEGOTIATED CONTESTATION IN PEACEBUILDING: MAINTAINING OR TRANSFORMING SYSTEMIC NARRATIVES?
}

\section{María Martín de Almagro Iniesta, Université Libre de Bruxelles and LUISS Guido Carli of Rome, Belgium}

In Strategic Narratives, the authors ask what counts as a victory when narratives in international security clash (Miskimmon et al., 2013, 103). They look at the importance of the narrative reception and contestation processes for explaining long-term change in international relations, all this at systemic, identity and issue levels. They argue that narratives draw upon pre-existing discourses and that contestation involves using media ecologies in innovative and skilful ways (ibid, 119). This may well be the case, but in examining contestation of peacebuilding narratives in post-conflict contexts it can only be the case if we, as I argue here, pay attention to contestation as a negotiation process. That is, if we consider the contestation of a strategic narrative not as an antagonist battle to be the hegemonic storyline, but as a dialogue on competing identities and issue boundaries narratives that in turn seek to adapt to the proposed new system narrative. Competing strategic narratives can therefore borrow elements from one another in a sort of hybridization process. Besides, those same narratives are modified by the materiality of the absorbed elements. In sum, understanding how contestation of a strategic narrative in peacebuilding works involves looking at the negotiation, silencing and appropriation of some of its elements so as to transform them.

There has been a shift in peacebuilding policy narratives in the West moving beyond the 1990's understanding of the liberal peace (e.g., Tellidis, 2012), based upon the 
existence of universal values, to a post-liberal understanding (e.g., policy documents from UNDP, 2009; EU DG for External Policies, 2012) that points to the need to reconsider the importance of local knowledge and local ownership. This shift is based upon the argument that rather than imposing Western practices, interventions need to empower local actors and to develop grassroots solutions. In the quest to enact this new peacebuilding narrative on the ground, local women associations have been constructed as key partners, under the argument that their feminine qualities make them ideal peace ambassadors. In addition, UN missions and reconstruction programs have used the UN Women, Peace and Security (WPS) agenda to stress the need to make women full participants in national decision-making and reconstruction processes and to support women grassroots initiatives for peacebuilding.

Recently, I have researched with an organisation called Dushirehamwe! (Let's reconcile!). Two women from the confronting ethnic groups in Burundi - one Hutu, one Tutsi - were hired by an international NGO to lead the association and establish focal points in every province. The aim was to foster reconciliation of women from the two ethnic groups through the creation of a unique identity of global sisterhood, as well as a shared understanding of past events and common future through trainings in mediation skills, involvement in public affairs and electoral processes as commanded by the WPS agenda. The reasoning behind these new identity and issue narratives was that this would help normalise and pacify relations amongst the two ethnicities and bring sustainable peace to local communities. Through their involvement in awareness raising and mediation trainings, local women accepted the identity narrative of peace makers, and understood the need to regain rights to participate and take decisions in the public sphere in order to have a more secured environment. Not long after, however, 
women associations asked for funding and support from international organisations to start a local campaign for the right of women to inherit. They argued that gender security involved economic security, and that, therefore, implementing the WPSA for a more peaceful Burundi and making of women ambassadors of peace required the drafting of inheritance laws.

On reflection, although their efforts have not been very successful until now and international actors have tried to silence these demands, these negotiations support my understanding of the ways identities and issue-boundaries are transformed, denaturalised and negotiated. By reinterpreting the issue boundaries of the WPS agenda and their identity narrative as peacemakers, women's associations have contested the system narrative of post-liberal peace put forward by Western proponents that for them focuses on a set of social associations, spaces and practices that reproduce economic and social relations, and therefore, the liberal system, instead of transforming it. These constructed identity narratives and issue narratives became strategic resources for local agents, providing them with opportunities for transformation of the system narrative. Richmond (2012) explains this same phenomenon and indicates that when local actors shift the terrain of peacebuilding into a conceptual and methodological space, it is very difficult for liberal peacebuilding to contest it.

These examples highlight the place of negotiation, silencing and appropriation of elements of narratives in their contestation. There is a need to look at the silences, adaptations and negotiations of narratives if we are to understand the meanings attributed to the narrative by its recipients. Paying attention to these individual negotiations can shape the researchers' analysis of the connections between the initial 
strategic narrative design and the various contestations that we might access. One way of looking at contestation of these narratives is to work with how new identity and issue boundaries provided by the strategic narrative are negotiated in order to adopt the system narrative.

\section{References}

EU Directorate General for External Policies. 2012 How the EU can Support Peaceful Post-

Election Transitions of Power: Lessons from Africa. Brussels: European Parliament.

Miskimmon, A., O’Loughlin, B. and Roselle, R. 2013. Strategic Narratives: Communication Power and the New World Order. New York: Routledge.

Ndacayisaba, G. 2007. "Enhancing Security and the Rule of Law: How can gender be better integrated into the priorities of the UN Peacebuilding Commission?" Speech before the Highlevel Roundtable on Gender and Security in Burundi and Sierra Leone, 5 June 2007. http://womenpeacesecurity.org/media/pdf-Goretti Speech June2007.pdf

Richmond, O. 2012. “A Pedagogy of Peacebuilding: Infrapolitics, Resistance and Liberation” International Political Sociology, 1-17.

Tellidis, I. 2012. "The End of the Liberal Peace? Post-Liberal Peace vs. Post-Liberal States", International Studies Review 14(3): 429-35.

UNDP 2009. Governance in Conflict Prevention and Recovery: A Guidance Note. New York: UNDP.

World Bank 2011. Development Report. Washington, DC: World Bank. 